\title{
TWIST2 wt Allele
}

National Cancer Institute

\section{Source}

National Cancer Institute. TWIST2 wt Allele. NCI Thesaurus. Code C127914.

Human TWIST 2 wild-type allele is located in the vicinity of $2 q 37.3$ and is approximately 63 $\mathrm{kb}$ in length. This allele, which encodes twist-related protein 2 , is involved in the modulation of osteogenesis. Mutation of the gene is associated with Ablepharonmacrostomia syndrome, Barber-Say syndrome, and Setleis type focal facial dermal dysplasia 3. 